Hydrol. Earth Syst. Sci., 15, 2621-2630, 2011

www.hydrol-earth-syst-sci.net/15/2621/2011/

doi:10.5194/hess-15-2621-2011

(C) Author(s) 2011. CC Attribution 3.0 License.

\title{
Spatial and temporal connections in groundwater contribution to evaporation
}

\author{
A. Lam ${ }^{1}$, D. Karssenberg ${ }^{1}$, B. J. J. M. van den Hurk ${ }^{2,3}$, and M. F. P. Bierkens ${ }^{1,4}$ \\ ${ }^{1}$ Department of Physical Geography, Utrecht University, Utrecht, The Netherlands \\ ${ }^{2}$ Institute of Marine and Atmospheric research IMAU, Utrecht University, Utrecht, The Netherlands \\ ${ }^{3}$ KNMI, De Bilt, The Netherlands \\ ${ }^{4}$ Deltares, Utrecht, The Netherlands
}

Received: 21 January 2011 - Published in Hydrol. Earth Syst. Sci. Discuss.: 1 February 2011

Revised: 5 August 2011 - Accepted: 9 August 2011 - Published: 24 August 2011

\begin{abstract}
In climate models, lateral terrestrial water fluxes are usually neglected. We estimated the contribution of vertical and lateral groundwater fluxes to the land surface water budget at a subcontinental scale, by modeling convergence of groundwater and surfacewater fluxes. We present a hydrological model of the entire Danube Basin at $5 \mathrm{~km}$ resolution, and use it to show the importance of groundwater for the surface climate.

Results show that the contribution of groundwater to evaporation is significant, and can locally be higher than $30 \%$ in summer. We demonstrate through the same model that this contribution also has important temporal characteristics. A wet episode can influence groundwater contribution to summer evaporation for several years afterwards. This indicates that modeling groundwater flow has the potential to augment the multi-year memory of climate models. We also show that the groundwater contribution to evaporation is local by presenting the groundwater travel times and the magnitude of groundwater convergence. Throughout the Danube Basin the lateral fluxes of groundwater are negligible when modeling at this scale and resolution. This suggests that groundwater can be adequately added in land surface models by including a lower closed groundwater reservoir of sufficient size with two-way interaction with surface water and the overlying soil layers.
\end{abstract}

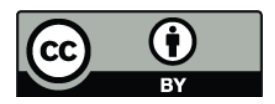

Correspondence to: D. Karssenberg (d.karssenberg@geo.uu.nl)

\section{Introduction}

In the last decades, the importance of land-surface - atmosphere feedbacks in climate has been more and more recognized. Precipitation recycling, the process from local evaporation to local precipitation, is one of the important land - atmosphere interactions in the climate system (e.g., Trenberth, 1999; Brubaker et al., 1993; Koster et al., 2004; Bisselink and Dolman, 2009).

The strength of this feedback has been estimated in terms of rainfall recycling ratio (Trenberth, 1999) and coupling strength, where the latter can be estimated in terms of precipitation amounts (e.g., Koster et al., 2004; Dirmeyer, 2005) or rainfall probability (Lam et al., 2007). Key to precipitation recycling from an atmospheric perspective is evaporation. From a terrestrial perspective, runoff is the key process (Savenije, 1996), as all water that runs off the land surface cannot contribute to evaporation and hence to precipitation recycling.

Just as the source of precipitation may be local (evaporation) or imported (by advection) (Trenberth, 1999), the source of evaporation may be local (from previous precipitation) or imported (by lateral transport). Terrestrial water has two major modes of lateral transport: surface water flow and groundwater flow. Both modes interact with soil moisture. Groundwater flows along a gradient that is usually dominated by the gradient in elevation, i.e. by topography. In flat terrains, in absence of topography-related gradients, groundwater is free to engage in lateral movements in any direction within aquifers, as gradients are dominated by gradients in aquifer downward (recharge) and upward (seepage, extraction, capillary rise) fluxes. So, it is possible for

Published by Copernicus Publications on behalf of the European Geosciences Union. 
groundwater to replenish episodic, local water shortages or to sustain a steady flux of water into regions that have a more persistent shortage of water. Surface water, on the other hand, flows along a predefined pattern (the river network), in a predefined direction (downstream). Sustained transport over large distances is normal, and contribution to the soil water in the land surface is possible via river - aquifer interactions.

Climate models suffer from a lack of "memory" in their land surface (Syroka and Toumi, 2001; Katul et al., 2007; Weisheimer et al., 2011). Once a soil column has been completely dry or thoroughly wet, it carries no signal from past events. Persistences of over a year are seldomly seen (Hirschi and Seneviratne, 2010). As groundwater flow is a slow process, it has been suggested that groundwater convergence may lead to persistence in surface climate (Bierkens and Van den Hurk, 2007; Maxwell and Miller, 2005; Maxwell and Kollet, 2008; Fan et al., 2007; Miguez-Macho et al., 2007; Anyah et al., 2008), although the effect of lateral flow has not yet been distinguished from the effect of in situ groundwater table dynamics (Yeh and Eltahir, 2005; Gulden et al., 2007; Ferguson and Maxwell, 2010; Fan and MiguezMacho, 2010b). On the one hand, a back-of-envelope calculation suggests that on the typical scale of a climate model, this effect should be small. On the other hand, the topology of the landscape could locally amplify the signal from groundwater convergence. The idea is that groundwater that has recharged in topographically higher areas flows towards (and converges to) lower exfiltration zones, mainly river valleys and wetlands, and sustains evaporation in the exfiltration zone either by capillary rise or by direct extraction of phreatophytes. Through the large inertia of groundwater systems wet periods from the past may then have an effect on increased evaporation in subsequent dry periods. By the evaporation - precipitation feedback (recycling) this may also affect warm season rainfall.

As lateral fluxes of groundwater (and surface water) are not represented in current climate models, the question arises how important this omission is. Does it hamper the reproduction of mass and energy balances of the land surface by climate models? As a first step to answering this question we employ a coupled groundwater-surfacewater model of the Danube basin to answer the following research questions.

1. What is the spatial and temporal contribution of groundwater to evaporation?

2. What are the temporal (multi-year) connections in the groundwater contribution, as reaction to anomalies?

3. What fraction of groundwater-supported evaporation is local, and what fraction is imported (by river or groundwater convergence)?

Studies that consider the first research question have been performed before (e.g., Bauer et al., 2006; Maxwell and Kol- let, 2008; Miguez-Macho et al., 2007; Anyah et al., 2008; Rihani et al., 2010; Yeh and Famiglietti, 2009). These studies were at meso-scale (kilometers to tens of kilometers spatial scale) and considered regions where topography is the prime control of groundwater flow. In those regions, and at those scales, groundwater is shown to play a significant role in the land surface climate. Our study, in contrast, is at the regional climate scale (hundreds of kilometers spatial scale), and focuses on large, relatively flat areas.

There are already some investigations into the third research question. For example, Schaller and Fan (2009) did a study over the USA where groundwater import and export was stipulated to close the river basin water balance of measured discharge, interpolated precipitation and modeled evaporation. Proof for inter-basin groundwater flow is offered by field studies, but again at a much smaller scale than we investigate here.

This paper is organized in five sections. The next section presents the Danube Basin as test bed for our research. Section 3 concerns our model, the climate forcing we used, and model calibration. In Sect. 4 we present the results and a discussion. In Sect. 5 we summarize the findings of our research and present general conclusions on spatial and temporal connections in the land surface water balance.

\section{The Danube Basin}

The Danube Basin is an interesting test-bed for our analysis for several reasons. Recent studies suggested a strong soil-moisture - precipitation feedback in parts of the basin (Seneviratne et al., 2006), regional climate models have shown a persistent dry bias in this region (e.g., Jacob et al., 2007; Kjellström et al., 2007) and the basin includes very large groundwater bodies. The Danube River Basin is the second largest river basin in Europe (after the Volga), covering around $800000 \mathrm{~km}^{2}$ in several countries and draining into the Black Sea (Regionale Zusammenarbeit der Donauländer, 1986).

The climate of the basin has a distinct W-E gradient. The upper reach of the Danube, in the Western part of the basin and north of the Alps, has an Atlantic influence. The middle and lower reach, in the eastern parts of the basin, have a more continental climate, with cold winters and dry summers. A reference hydroclimatology is given by Domokos and Sass (1990). The Pannonian Plain (region A in Fig. 1) is a region with very flat terrain. Quaternary lake and river deposits have a thickness up to $500 \mathrm{~m}$, and both these and underlying deposits are large groundwater reservoirs. This plain is crossed by several rivers, of which the Danube (in its middle reach) and the Tisza are the largest. The Wallachian Plain (region B in Fig. 1) is a region with major groundwater reservoirs in the lower reach of the Danube. This plain has a history similar to the Pannonian Plain, with Quaternary uplift of the Karpathian mountains, regional basin subsidence 


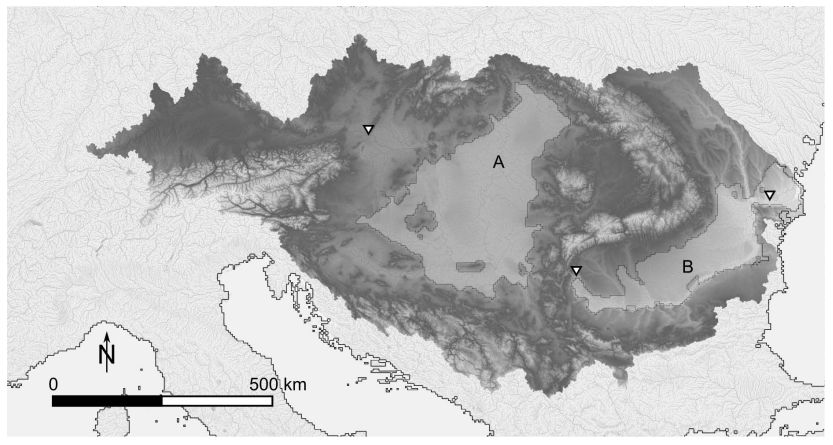

Fig. 1. Map of the Danube Basin. The regions labeled A and B are flat terrains where we modelled groundwater using MODFLOW. Region A is in the text referred to as the Pannonian Plain, region B the Wallachian Plain. The symbols $\nabla$ mark the river discharge measurement stations Bratislava, Iron Gate and Ceatal Izmail (from West to East).

and sedimentary aggradation. A major difference between the two regions is that the baselevel of the Wallachian Plain is determined by the Black Sea, its great oscillations contributing to the formation of incised river valleys throughout this region (Radoane et al., 2003; Gilbrich et al., 2001).

\section{Modeling terrestrial water in the Danube Basin}

\subsection{Model framework and domains}

The model is a modular, distributed, grid-based model, developed in the PCRaster environment (Wesseling et al., 1996; Karssenberg et al., 2007). We chose a 7 day timestep and a $5 \mathrm{~km}$ grid cell size. Figure 2 shows a schematic of the model set-up, in both the "steep" and the "flat" terrains. The "steep" terrains are all regions within the Danube Basin except the two recognized "flat" regions: the Pannonian and Wallachian Plains (A and B in Fig. 1).

\subsection{Climate forcing}

The model was forced by the $50 \mathrm{yr}(1950-2000), 1^{\circ}$ resolution, daily, global meteorological forcing dataset (Sheffield et al., 2006). This dataset has been compiled from several sources and is homogenized for improved consistency between parameters. The coarse resolution of the dataset introduces unwanted contrast at the edges of the climate grid cells (see Fig. 3, upper panel). The climate data were downscaled using empirical lapse rates that were derived using nearby forcing data grid points. The resulting daily fields were temporally upscaled to the weekly time step of our model by taking the simple mean. This approach does not result in optimal estimates for each variable, but preserves local consistency between variables. The bottom panel of Fig. 3 shows a typical result of this downscaling for temperature. The con-

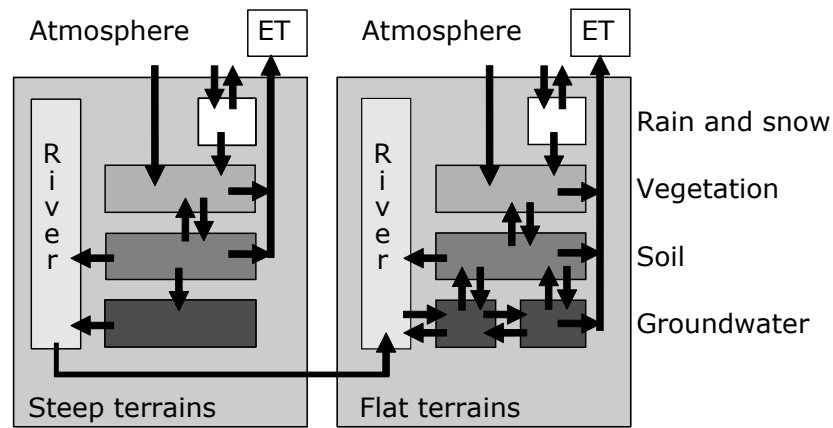

Fig. 2. Model schematics. In steep terrains (left) Groundwater contribution to runoff is modeled by a linear reservoir at each gridcell. In contrast, in flat terrains (right), groundwater level and flow is modeled with MODFLOW, allowing spatial interactions as well as (vertical) interactions with the land surface. The land surface components - vegetation, soil and surface water - are the same in both domains.

trast at the edges of the climate date grid cells is clearly reduced when compared to the original.

\subsection{Vegetation and snow cover}

The snow pack intercepts all precipitation, whether in the form of snow or rain. Precipitation at temperatures $0^{\circ} \mathrm{C}$ or below is assumed to be solid (snow), above $0^{\circ} \mathrm{C}$ it is assumed to be rain. The snow pack can intercept rain only up to a certain fraction. If there is too much liquid water in the snow pack, it is removed as runoff. Liquid snow water is assumed to refreeze, allowing for more than one rainy episode per season.

A temperature index (degree-day) snowmelt method (see e.g., Hock, 2003) was used to model snow melt. Snow melt $M_{\mathrm{t}}$ is modeled as $M_{\mathrm{t}}=f_{\mathrm{m}} \cdot T^{+} \Delta t$ where $f_{\mathrm{m}}$ is the snow melt factor, and $T^{+}$is the cumulative positive difference between daily average temperature $T_{\text {avg }}$ and melting threshold temperature $T_{0}$ during the time step $\Delta t$.

The constant $T_{0}$ slightly deviates from the standard melting temperature of $273 \mathrm{~K}$ to arrive at reasonable rates of snow cover disappearance in spring.

Snow evaporation or sublimation is a process that is notoriously difficult to model, as it depends on wind, radiation, snow albedo, snow compaction and several vegetation characteristics including snow interception characteristics (Pomeroy et al., 1998). As the necessary information is not available, snow evaporation is not included as a process in the model. Instead, we employ a simple correction factor at snow melt to avoid overestimating river discharge.

\subsection{Soil water and evaporation}

The soil water balance reads

$\Delta S=P+M_{\mathrm{t}}-E-R_{\mathrm{gw}}-Q_{\mathrm{r}}$. 
Liquid precipitation $P$ and snowmelt $M_{\mathrm{t}}$ add to the soil water budget; evaporation $E$, groundwater recharge $R_{\mathrm{gw}}$ and runoff $Q_{\mathrm{r}}$ subtract from the budget. The net effect of all these fluxes is $\Delta S$, the change in soil water storage. All parts of the equation are fluxes of water (mass/area/time, simplified as length/time).

The downward soil water flow $q\left[\mathrm{~m} \mathrm{~d}^{-1}\right]$ is modeled after Campbell (1974), the conductivity $k$ and the pressure head $\psi$ [m] of a soil depends on its water content $W$ [dimensionless].

$$
\begin{aligned}
q & =-k\left(\frac{d \psi}{d z}+1\right) \\
\psi & =\psi_{\text {sat }}\left(\frac{W}{W_{\text {sat }}}\right)^{-b} \\
k & =k_{\text {sat }}\left(\frac{W}{W_{\text {sat }}}\right)^{2 b+3}
\end{aligned}
$$

We use the FAO Soil Map of the World (FAO, 1998) with the commonly used parameterset of Clapp and Hornberger (1978) to distinguish soil classes and arrive at estimates for $W_{\text {sat }}, \psi_{\text {sat }}, k_{\text {sat }}$ and $b$ (Braun and Schädler, 2005). Evaporation demand $E_{0}$ is computed using the standard FAO Penman Monteith method (Allen et al., 1998). The evaporation demand is met, in order of preference, by fluxes out of interception store $E_{\mathrm{c}}$, out of soil water $E_{\mathrm{swc}}$, and in flat areas by capillary rise out of the groundwater $E_{\mathrm{gw}}$ (Eq. 5). The potential flux out of interception store $E_{\text {c.pot }}$ during a timestep is limited only by the amount in store $S_{\mathrm{c}}$. The potential flux out of soil water $E_{\text {s.pot }}$ is limited by the amount in store $S_{\mathrm{s}}$, and by the conductivity of the soil. The potential flux out of the groundwater $E_{\mathrm{gw} \text {.pot }}$ is limited by the amount of groundwater above a threshold level $-5 \mathrm{~m}$, which is determined by the relative groundwater level $H_{\text {rel }}$ (groundwater level - surface level) and specific yield of the aquifer (taken equal to $\left.W_{\text {sat }}\right)$, and the conductivity of the unsaturated zone above the aquifer (taken equal to $k$ ), and spatially limited to the flat areas.

$$
E= \begin{cases}E_{0}, & \text { for } E_{o} \leqslant E_{\text {c.pot }}, \\ E_{\text {c.pot }}+\left(E_{0}-E_{\text {c.pot }}\right), & \text { for } E_{\text {c.pot }} \leqslant E_{0} \leqslant E_{\text {c.pot }}+E_{\text {s.pot }}, \\ E_{\text {c.pot }}+E_{\text {s.pot }}+\min \left(E_{\mathrm{gw} . p o t},\right. & \\ \left.E_{0}-\left(E_{\text {c.pot }}+E_{\text {s.pot }}\right)\right), & \text { for } E_{0}>E_{\text {c.pot }}+E_{\text {s.pot }} .\end{cases}
$$

$$
E_{\mathrm{c} . \mathrm{pot}}=S_{\mathrm{c}} / \Delta t
$$

$E_{\mathrm{s} . \mathrm{pot}}=\min \left(S_{\mathrm{s}} / \Delta t, k\right)$

$E_{\mathrm{gw} . p o t}=\left\{\begin{aligned} \min \left(\left(-5-H_{\mathrm{rel}}\right) W_{\mathrm{sat}},\right. & \\ \left.-k\left(\frac{\psi_{\mathrm{sat}}-\psi}{-H_{\mathrm{rel}}-1}+1\right)\right), & \text { for } H_{\mathrm{rel}} \geqslant-5 \\ 0, & \text { for } H_{\mathrm{rel}}<-5\end{aligned}\right.$

In flat areas, capillary rise that is not immediately consumed for evaporation is added to the soil, i.e. it is not "thrown back" into the aquifer or into runoff. It is subsequently available for evaporation.

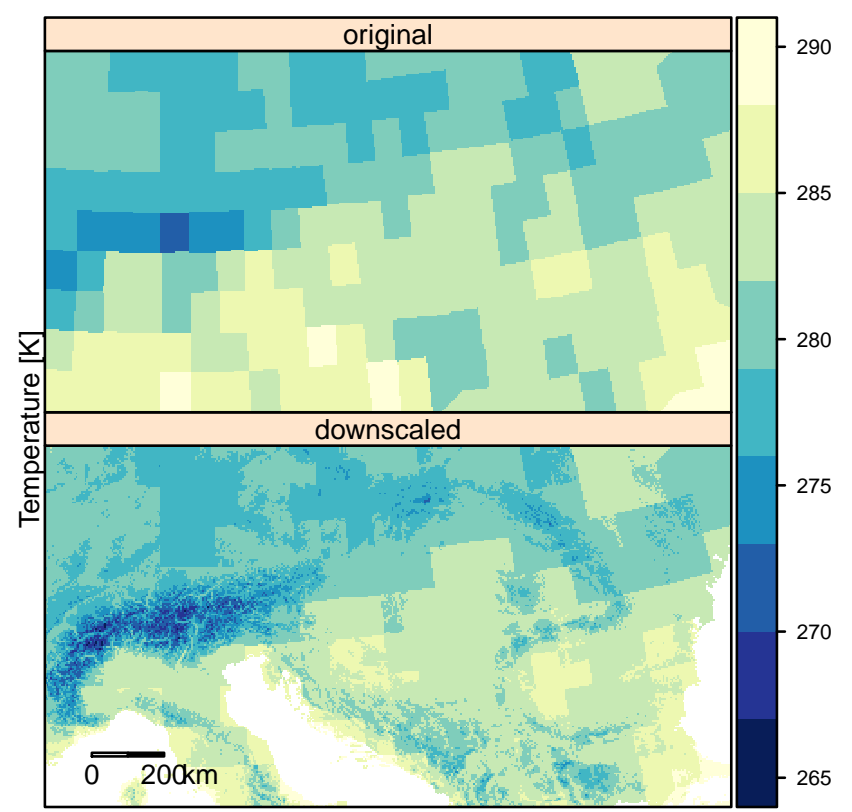

Fig. 3. Downscaling of climate variables. The panels have the same domain as Fig. 1. The upper panel shows the mean temperature on an arbitrary day, on the scale of the climate dataset (resolution $\pm 100 \mathrm{~km}$ ). The lower panel shows the downscaled temperature on the model scale (resolution $5 \mathrm{~km}$ ).

\subsection{Groundwater and rivers}

Groundwater in steep terrain has a contribution to the river discharge $Q_{r}$ mainly as baseflow. We model the groundwater contribution to discharge by a linear reservoir. The baseflow at any timestep is given by $Q=S / \alpha$, with $S$ the groundwater store and $\alpha$ the reservoir coefficient.

In the geologic setting of the Pannonian and Wallachian Plains, it is clear that the flat terrains contain the thick aquifers. In these areas, the groundwater flow is not primarily topography driven, and groundwater flow is twodimensional. Therefore the groundwater is modeled by MODFLOW (Harbaugh et al., 2000). The deliniation of the two domains is based on topography, where the plains modeled by MODFLOW are two contiguous regions with less than $0.5 \%$ of slope, with no-flow boundary conditions. We use MODFLOW coupled into the model framework, as in Schmitz et al. (2009). We used spatially uniform aquifer properties, consistent with values obtained from Regionale Zusammenarbeit der Donauländer (1986). This also allows a double-check of the computed lateral fluxes by derivation of steady-state fluxes given the groundwater head at any timestep. The aquifers in the plaines are recharged by percolation of soil water, and by interaction with rivers. The source of the river water is the upstream surface water network.

The surface water drainage network is obtained from a SRTM-derived digital elevation model (Jarvis et al., 2008). All rivers have an equilibrium width and incision depth 


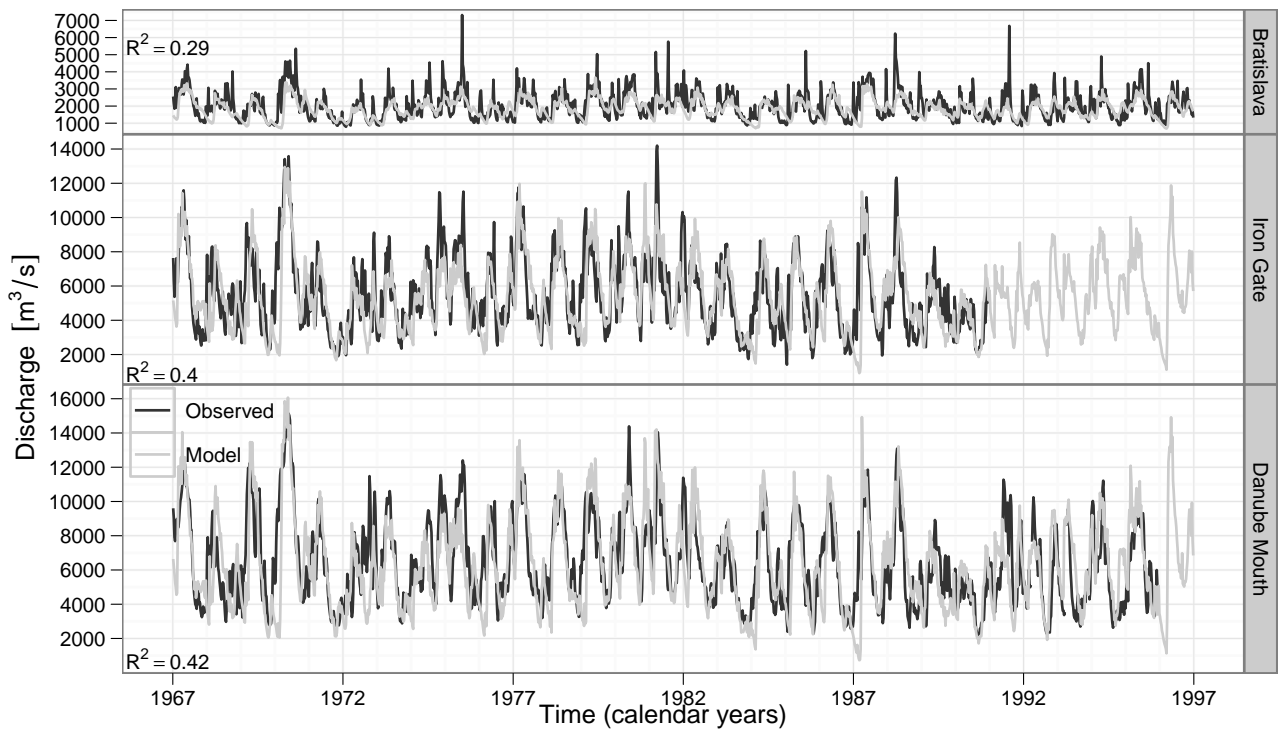

Fig. 4. Example hydrographs resulting from calibration. See Fig. 1 for the location of gauging stations Bratislava, Iron Gate and Danube Mouth (Ceatal Izmail).

according to Lacey's formula (see Savenije, 2003 for details and discussion). Rivers have interaction with aquifers (Sophocleous, 2002) so that they can locally recharge or drain the aquifer. We assume that a saturated connection between river and aquifer exists at all times. Then $R=$ $-k_{\text {sat }} \frac{\Delta H}{L}$ where $\Delta H$ is the difference between river level and groundwater level, $L$ is a calibrated river bed thickness, and $\mathrm{R}$ is the surface water - groundwater interaction flux per unit of river length in a cell. This equation also dictates the recharge at the aquifer boundaries. By setting boundary conditions of MODFLOW to "no-flow" we preserve the mass balance.

\subsection{Calibration}

The model was manually calibrated. We stress that we use this model only as a numerical laboratory to investigate the plausibility of groundwater contribution to the land surface water balance, and that discharge prediction was not a goal in constructing this model. Figure 4 shows time series of calibrated versus measured discharge, obtained from the Global Runoff Data Centre (GRDC), at the three measuring stations. In the upstream parts, shown by the Bratislava time series, the calibrated discharge reacts somewhat slower to changes in input than the measured discharge. In the middle and lower reaches, as shown by the Iron Gate and Danube Delta time series, respectively, modeled and measured discharges are in good agreement both by volume and by timing.

\section{Results and discussion}

\subsection{Groundwater contribution to evaporation}

The main difference between our model and usual Land Surface Models (LSMs) is the inclusion of groundwater bodies and rivers. The groundwater and river compartments in our model produce both local (vertical) and lateral (horizontal) mass fluxes, fluxes that are absent in usual LSMs. To assess the spatial and temporal contribution of groundwater to evaporation, it should be noted that this contribution has a direct and indirect component. In dry conditions, evaporation is possible directly from the groundwater. The indirect component is capillary rise: vertical flow from the groundwater table to the soil. The model keeps account of all fluxes in and out of the soil and thus the composition of soil water with respect to source is known. We assume perfect mixing of the soil water (or, equivalently, vegetation indifference with respect to water provenance) such that the relative contribution of groundwater to evaporation is equal to the relative content of groundwater-sourced soil water. To some extent, memory of the land surface can be augmented by deepening the soil column. However, there are LSMs in Global Climate Models (GCMs) and Regional Climate Models (RCMs) with soils deeper than $2 \mathrm{~m}$ that still show a continental bias as result of the "memory loss" (Hirschi et al., 2007), of which HTESSEL (Balsamo et al., 2009) is one example. As Gulden et al. (2007) demonstrate, increasing the depth of the soil column is certainly no proven remedy, and less robust to parametrize than a local groundwater table. Moreover, even if it were a remedy, we would still be more interested in modeling these slower physical processes than in just accounting for their effects by employing deeper and deeper soils. 


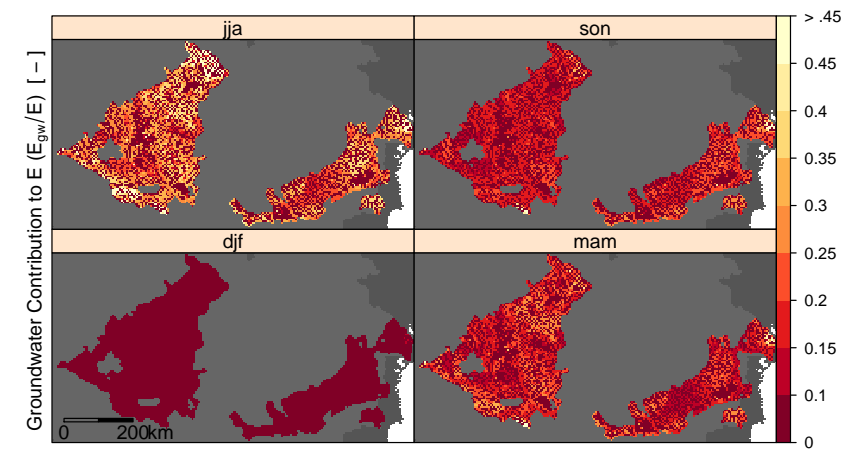

Fig. 5. Relative groundwater contribution to evaporation, per season. In winter (lower left), groundwater does not contribute to evaporation. From spring to late fall, there is a significant contribution of groundwater to sustain evaporative fluxes.

Adding rivers to the LSM is also an attempt to describe all parts of the terrestrial hydrological cycle. In our formulation, the groundwater reservoirs in the 'steep' areas deliver water to the rivers, and the rivers deliver this water to the boundaries of the aquifer, where it recharges the groundwater. This model concept mimics the role of alluvial fans and similar geomorphological structures at the edge of large basins for aquifer recharge, rather than the deep groundwater seepage from the surrounding hardrock.

The $E_{0}$ formulation by Penman-Monteith is a standard. The approach of meeting the demand preferentially by the different stores is present in many GCM/LSM formulations (e.g. canopy stores are the first to supply to E), but a sophisticated allocation algorithm of stores is absent in our model. Evaporative demand $E_{0}$ in the Penman-Monteith formulation does not depend on soil moisture. Moisture stress is handled by representing a limited supply, which involves the suction of soil moisture (Eqs. 4, 7). This is essentially similar to the approach in most land surface schemes used in GCMs, which usually carry a soil moisture dependent surface resistance in their representation of the Penman-Monteith equation.

Figure 5 shows the importance of groundwater contribution to evaporation. In winter (lower left), groundwater does not contribute to evaporation, due to small evaporation demand, and due to snow cover. In all other seasons, groundwater contributes to evaporation significantly, in both the Pannonian and the Wallachian Plains. The patchy pattern of groundwaters contribution to evaporation is caused by the river network. In areas where rivers are incised, the groundwater levels are influenced by the low-lying rivers. The groundwater level is close to the surface near the river, and is deeper below the surface in the surrounding area. The surrounding area is large compared to the area of the incised river. On average, the groundwater level is therefore more likely to stay below the interaction level of $5 \mathrm{~m}$ below the land surface.

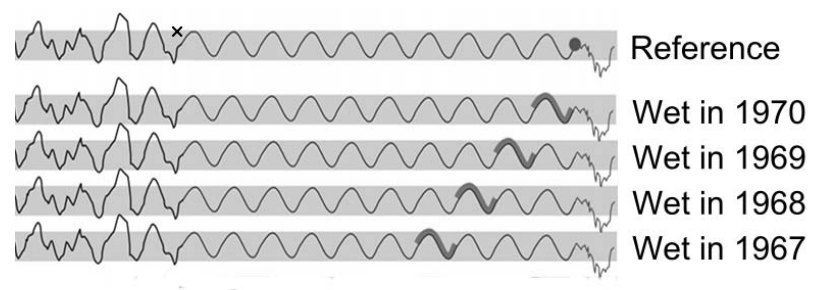

Fig. 6. Climate forcing sequences for estimating persistence in the coupled system. Irregular pattern denotes unaltered climate forcing (left, and right). At the "x" starts the cyclic median climate forcing. The grey $\sim$ on top of the regular wave symbolizes a wet anomaly. The grey dot is symbol for the year 1971 .

The choice of $5 \mathrm{~m}$ below the land surface as threshold is more or less arbitrary, but we observe some constraints. A much shallower table (say, $2 \mathrm{~m}$ ) would prohibit interaction even when the groundwater level is still in the root zone. Our choice of $-5 \mathrm{~m}$ is well below the local rooting depth of dominant vegetation types in our region of interest (Masson et al., 2003). On the other hand, successively deeper thresholds (say, to $15 \mathrm{~m}$ ) would increase the possibilities of interaction. Our choice is in good accordance with the "extinction depths" found by Shah et al. (2007).

The relations between appropriate scale in space and time, and the scope and scale of the problem at hand, and the scale and granularity of model inputs, are important. A resolution of $5 \mathrm{~km}$ is very fine in comparison with the climate inputs, and also in comparison with GCMs and RCMs. On the other hand, this scale is required to mimick the deepest nested groundwater systems according to Tóth (1963). Similarly, the 7-day timestep is adequate for the description of the seasonal cycle of the surface climate, including onset and length of dry spells. We find that in comparison with the seasonal variation of interaction with the slowly reacting groundwater store that we investigate here, our choice is appropriate for the scale and variability of the processes in question.

\subsection{Temporal persistence in the coupled system}

We show that at our scale of investigation the "vertical" contribution of groundwater to the land surface water balance is significant. Our second research question is about temporal (multi-year) connections in the groundwater system. The extra water pathway of precipitation - soil water percolation aquifer recharge - capillary rise - evaporation influences the land surface by means of a memory effect. We investigate this memory effect by applying a precipitation perturbation and show for how long this perturbation effects evaporation.

The setup is as follows, and illustrated in Fig. 6. The model was run several times, each run starting with the same initial conditions. Each run was forced by $10 \mathrm{yr}$ of unaltered climate forcing (Sheffield et al., 2006) (left black $\mathrm{x}$ in Fig. 6) as a spin-up period, followed by 10 yr (1961-1970) 


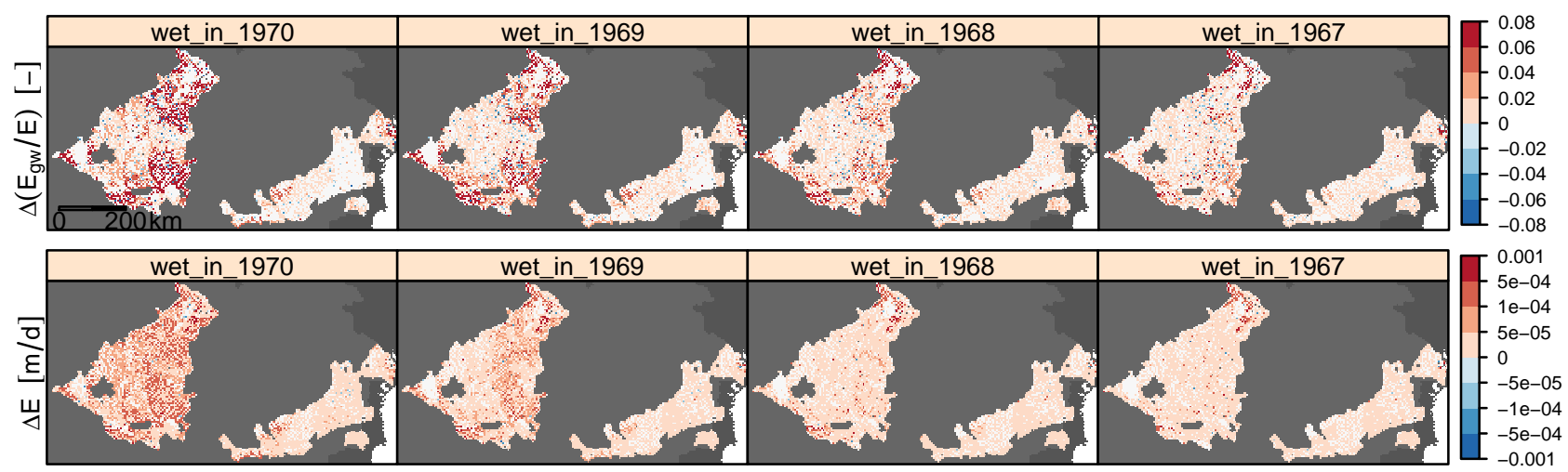

Fig. 7. Temporal persistence of summer evaporation and groundwater contribution to summer evaporation. Shown here is the difference in evaporation $\Delta E$ and the difference in groundwater contribution to evaporation $\Delta\left(E_{\mathrm{gw}} / E\right)$ in a dry summer (1971) after $10 \mathrm{yr}$ of cyclic median climate forcing, compared to the same forcing except supplemented with a wet anomaly in the year just before (wet in 1970), two years before (wet in 1969), etc.

in which the historic forcing time series is replaced by the mean annual cycle in the dataset of Sheffield et al. (2006) (symbolized by the regular wave pattern in Fig. 6) to arrive at a cyclic equilibrium state of the land surface. Then (right grey dot in Fig. 6) unaltered climate forcing was applied for 1971, a very dry year in Europe.

Subsequent runs each had an anomalous wet year in the cyclic median climate forcing, symbolized by the grey $\sim$ on top of the regular wave. For each next run the anomaly was shifted one year back in time. The anomaly is constant throughout the year, so that the total precipitation during an anomalous year is at the 90th percentile of yearly precipitation in the dataset of Sheffield et al. (2006). The varying lead time allows to evaluate the lagged effect of the perturbation at a range of time intervals, varying from one to five years.

Figure 7 shows that several large parts of the Pannonian Plain and a few small areas in the west of the Wallachian Plain receive more groundwater for evaporation when the wet anomaly is one year before the dry summer. When the anomaly recedes in time, both the area and the magnitude of change in groundwater contribution to evaporation reduces. The contrasting behaviour of the two regions is due to the fact that in most parts of the Wallachian Plain the equilibrium groundwater table is lower than $5 \mathrm{~m}$ below the surface, effectively prohibiting interaction between aquifer and land surface. The increased groundwater recharge during a single wet year is insufficient to raise the groundwater level above the interaction threshold of $5 \mathrm{~m}$ below the surface. The land surface and the aquifer stay uncoupled. In the Pannonian Plain however, there are more regions where the increased recharge raises the water table above the interaction threshold, and also more regions were the equilibrium water table is above the interaction threshold even in absence of a wet anomaly. The wet anomaly is visible in the land surface water balance for up to $4 \mathrm{yr}$.

\subsection{Contribution of imported groundwater to evaporation}

Our model simulates two modes of lateral transport that can possibly contribute to evaporation: transport by river and transport by groundwater flow. Groundwater is free to engage in lateral movements in any direction within the aquifers, so it would be possible to replenish localized shortages or sustain a steady flux of water into regions that have stronger coupling with atmosphere. To calculate the importance of these processes, we derive both groundwater velocity $v\left[\mathrm{yr} \mathrm{km}^{-1}\right.$ in a lateral direction] and convergence $c_{\mathrm{gw}}\left[\mathrm{md}^{-1}\right.$ in the vertical] using the spatial distribution of groundwater level $H$ and aquifer conductivity $k$ and porosity $n$ :

$$
\begin{gathered}
v=\frac{k \nabla H}{n} \\
c_{\mathrm{gw}}=\nabla^{2} H
\end{gathered}
$$

Figure 8 is a map of equilibrium groundwater travel velocity $v$, in $\mathrm{yr} \mathrm{km}^{-1}$. This map shows that the time scale to transport water in the subsurface between adjacent cells (with a cell size of $5 \mathrm{~km}$ ) is at minimum tens of years, and at maximum tens of thousands of years. We may note as an aside that atmospheric processes that transport water and share the same spatial scale and also interact with the land surface (e.g. cloud formation, storms, fronts) have typical time scales of hours to days, i.e. 4-6 orders of magnitude faster. The typical timescale is a telltale, but not sufficient to disprove the importance of lateral groundwater flow to the surface climate. For this, we also need to quantify the flux of water that the groundwater system makes available to the land surface.

Figure 9 shows that the typical magnitude of the groundwater convergence flux $c_{\mathrm{gw}}$ is in the order of $10 \times 10^{-7} \mathrm{~m} \mathrm{~d}^{-1}$. At this rate, the groundwater convergence 


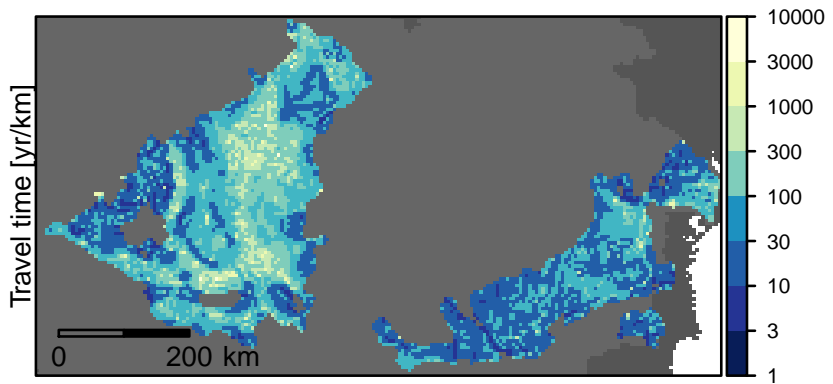

Fig. 8. Travel time of groundwater, in $\mathrm{yr} \mathrm{km}^{-1}$.

takes years to supply for one hour of summer evaporation. The expectation that lower-lying basins receive groundwater from the surrounding hills and mountains, is met by our simulation: along the boundaries of the two basins, export of groundwater (out of the boundary cells, into the domain) is prevalent. The water pathways exist and the fluxes can be estimated, although they are of no importance to the surface climate in our model experiment.

The previous studies mentioned in the introduction already show the importance of lateral flow at finer resolution and steeper slopes. We expect that finer resolution alone will make lateral groundwater flow much more important, firstly because slopes will be steeper (see for example Fan and Miguez-Macho, 2010a) and secondly because much more flow will be lateral, allbeit on the finer scale in the deeply nested system (Tóth, 1963). We expect that a finer scale in the spatial sense may imply a larger effect on short-term memory, and a smaller effect on long-term memory of the land surface model in these areas. Areas of greater topographic relief are difficult to predict in this respect. They are much better drained (more intricate and deeper incised river channels) than flat areas, so we expect that the large-scale lateral subsurface flow will not be voluminous. The elements of scale and of fractional dimensionality of the topography and of the groundwater level have to be taken into account when comparing results from different studies. In this view, the contradiction between our and previous results may not be insurmountable.

The travelling times that we derived at a spatial resolution of $5 \mathrm{~km}$ indicate that the inclusion of lateral groundwater flow in deep aquifers under flat terrain only becomes useful when investigating at time scales of thousands of years.

It can be concluded that in the Danube region, the contribution of large-scale lateral groundwater flow to the land surface water balance, and therefore to the land surface climate, is negligible. One caveat is that the modelled region in this study is relatively flat, so that the difference in groundwater storage between regions becomes the major gradient that drives the groundwater flow. Differences in groundwater storage in this region are determined by gradients in climate forcing, soil properties or vegetation properties at the appro-

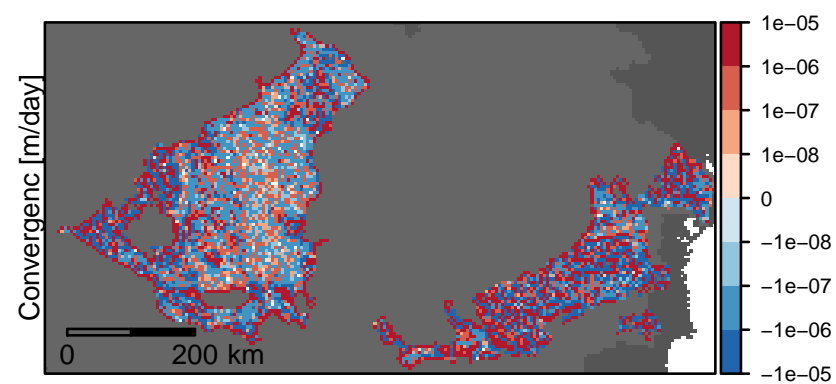

Fig. 9. Magnitude of groundwater convergence $\left(c_{\mathrm{gw}}\right)$, in $\mathrm{md}^{-1}$. Positive (red) values are divergent areas, where there is a net groundwater export. Negative (blue) values are convergent areas, with a net groundwater import.

priate scale. That is not to say that lateral groundwater flow plays no role in the land surface climate, but that at the scale of our investigation, and also at the scale of current climate models, it can be regarded as a local interaction.

\section{Conclusions}

The goal of this research was to investigate the importance of groundwater and groundwater convergence to the regional scale evaporation and through this on regional land surface climate. We built a coupled groundwater-soil moisturesurface water model of the Danube Basin, where landsurface - precipitation feedbacks are expected to be significant.

We show that groundwater is important as a source for dry season evaporation and we show that, at the scale of GCMs or RCMs and in flat terrain, horizontal redistribution and convergence of groundwater is not important as a source for evaporation. Groundwater contribution to dry season evaporation is significant in the two large groundwater basins considered, with relative contributions up to $30 \%$ and absolute area average rates over $1 \mathrm{~mm} \mathrm{~d}^{-1}$ in the Pannonian Plain (Fig. 5). This analysis does not include the added effect on evaporation by irrigation from both groundwater and surface water, which may be significant. Vertical groundwater flow (aquifers interacting with soil and rivers) is an important contributor to the land surface water balance, and should not be neglected in land surface models. A groundwater component in a land surface model allows explicit inclusion of the effects of capillary rise and thresholds in groundwater depth, which can not be achieved by enlargement of the soil water reservoir.

At resolutions and time scales that are usual for climate models, lateral groundwater flow under flat terrain can be neglected. From analysis of travel times and convergence rates follows that the travel times are too large and the fluxes too small to influence the land surface water balance and the surface climate. However, lateral subsurface flow takes place, 
and it would fit LSMs to describe all aspects of terrestrial water storage and transport, such that even when the water balance is not closed, the water cycle is.

We also show that large groundwater basins can be the cause of a significant multi-year local persistence to dry season evaporation, which is not included in current land surface models. The groundwater component in this model significantly improves the persistence of the water cycle, regionally adding up to $5 \mathrm{yr}$ of delayed evaporation response to a wet episode.

The limited importance of lateral groundwater flow shows that these effects could be incorporated by replacing the leaky lower soil reservoir of a land surface model in flat sedimentary basins with a large capacity groundwater reservoir with zero bottom flux and the possibility of draining to the surface water only. However, compared to the costs of running an atmospheric model, running a groundwater model as part of the land-surface model is computationally cheap. Adding transport of runoff by rivers and transport by aquifers, with two-way interaction with the soil, mends a gap in the modeled hydrological cycle, and can be instrumental to represent essential timescales/memory in land surface modeling. Future work comprises the extension of a RCM with our coupled river- and groundwater model, to investigate groundwaters influence on the land surface climate.

Acknowledgements. This research was sponsored by the Netherlands Organization for Scientific Research NWO, within the Water programme.

Edited by: Y. Fan

\section{References}

Allen, R., Pereira, L., Raes, D., and Smith, M.: Crop Evapotranspiration: Guidelines for Computing Crop Requirements, Irrigation and Drainage Paper no. 56, FAO, Rome, Italy, 1998.

Anyah, R. O., Weaver, C. P., Miguez-Macho, G., Fan, Y., and Robock, A.: Incorporating water table dynamics in climate modeling: 3. Simulated groundwater influence on coupled land-atmosphere variability, J. Geophys. Res., 113, D07103, doi:10.1029/2007JD009087, 2008.

Balsamo, G., Beljaars, A., Scipal, K., Viterbo, P., Van den Hurk, B., Hirschi, M., and Betts, A. K.: A Revised Hydrology for the ECMWF Model: Verification from Field Site to Terrestrial Water Storage and Impact in the Integrated Forecast System, J. Hydromet., 10, 3, 623-643, doi:10.1175/2008JHM1068.1, 2009.

Bauer, P., Gumbricht, T., and Kinzelbach, W.: A regional coupled surface water/groundwater model of the Okavango Delta, Botswana, Water Resour. Res., 42, W04403, doi:10.1029/2005WR004234, 2006.

Bierkens, M. F. P. and Van den Hurk, B. J. J. M.: Groundwater convergence as a possible mechanism for multi-year persistence in rainfall, Geophys. Res. Lett., 34, 5, 2007.

Bisselink, B. and Dolman, A. J.: Recycling of moisture in Europe: contribution of evaporation to variability in very wet and dry years, Hydrol. Earth Syst. Sci., 13, 1685-1697, doi:10.5194/hess-13-1685-2009, 2009.

Braun, F. and Schädler, G.: Comparison of soil hydraulic parameterizations for mesoscale meteorological models, J. Appl. Meteorol., 44, 1116-1132, 2005.

Brubaker, K. L., Entekhabi, D., and Eagleson, P. S.: Estimation of continental precipitation recycling, J. Climate, 6, 1077-1089, 1993.

Campbell, G. S.: A simple method for determining unsaturated conductivity from moisture retention data, Soil Sci., 117, 311-314, 1974.

Clapp, R. B. and Hornberger, G. M.: Empirical equations for some soil hydraulic properties, Water Resour. Res., 14(4), 601-604, 1978.

Dirmeyer, P. A.: The land surface contribution to the potential predictability of boreal summer season climate, J. Hydrometeorol., 6, 618-632, 2005.

Domokos, M. and Sass, J.: Long-term water balances for subcatchments and partial national areas in the Danube Basin, J. Hydrol., 112, 267-292, 1990.

Fan, Y. and Miguez-Macho, G.: A simple hydrologic framework for simulating wetlands in climate and earth system models, Clim. Dynam., 37, 253-278, doi:10.1007/s00382-010-0829-8, 2010a.

Fan, Y. and Miguez-Macho, G.: Potential groundwater contribution to Amazon evapotranspiration, Hydrol. Earth Syst. Sci., 14, 2039-2056, doi:10.5194/hess-14-2039-2010, 2010 b.

Fan, Y., Miguez-Macho, G., Weaver, C. P., Walko, R., and Robock, A.: Incorporating water table dynamics in climate modeling: 1. Water table observations and equilibrium water table simulations, J. Geophys. Res., 112, D10125, doi:10.1029/2006JD008111, 2007.

FAO: Digital Soil Map of the World, Tech. rep., Food and Agriculture Organization of the United Nations (FAO), Rome, Italy, 1998.

Ferguson, I. M. and Maxwell, R. M.: Role of groundwater in watershed response and land surface feedbacks under climate change, Water Resour. Res., 46, W00F02, doi:10.1029/2009WR008616, 2010.

Gilbrich, W. H., Krampe, K., and Winter, P.: Internationale Hydrogeologische Karte von Europa, 1:1.500.000, Bemerkungen zum Inhalt und Stand der Bearbeitung, Hydrol. Wasserbewirts., 45, 122-125, 2001.

GRDC: The Global Runoff Data Centre, Koblenz, Germany.

Gulden, L. E., Rosero, E., Yang, Z.-L., Rodell, M., Jackson, C. S., Niu, G.-Y., Yeh, P. J.-F., and Famiglietti, J.: Improving landsurface model hydrology: is an explicit aquifer model better than a deeper soil profile?, Geophys. Res. Lett., 34, L09402, doi:10.1029/2007GL029804, 2007.

Harbaugh, A., Banta, E., Hill, M., and McDonald, M.: MODFLOW-2000, the US Geological Survey modular groundwater model - user guide to modularization concepts and the ground-water flow process, Tech. rep., USGS Open-File Report 00-92, USGS, Reston, Virginia, 2000.

Hirschi, M., Seneviratne, S. I., Hagemann, S., and Schär, C.: Analysis of seasonal terrestrial water storage variations in regional climate simulations over Europe, J. Geophys. Res., 112, D22109, doi:10.1029/2006JD008338, 2007.

Hirschi, M., and Seneviratne, S. I.: Intra-annual link of spring and 
autumn precipitation over France, Climate Dynamics Volume 35, Numbers 7-8, 1207-1218, doi:10.1007/s00382-009-0734-1, 2010 .

Hock, R.: Temperature index melt modelling in mountain areas, J. Hydrol., 282, 104-115, doi:10.1016/S0022-1694(03)00257-9, 2003.

Jacob, D., Bärring, L., Christensen, O., Christensen, J., de Castro, M., Déqué, M., Giorgi, F., Hagemann, S., Hirschi, M., Jones, R., Kjellström, E., Lenderink, G., Rockel, B., Sánchez, E., Schär, C., Seneviratne, S., Somot, S., van Ulden, A., and van den Hurk, B.: An inter-comparison of regional climate models for Europe: model performance in present-day climate, Climatic Change, 81, 31-52, doi:10.1007/s10584-006-9213-4, 2007.

Jarvis, A., Reuter, H., Nelson, A., and Guevara, E.: Hole-filled seamless SRTM data V4, Tech. rep., International Centre for Tropical Agriculture (CIAT), , available at: http://srtm.csi.cgiar. org (last access: 31 January 2010), 2008.

Karssenberg, D., de Jong, K., and van der Kwast, J.: Modelling landscape dynamics with Python, Int. J. Geogr. Inf. Sci., 21, 483495, doi:10.1080/13658810601063936, 2007.

Katul, G. G., Porporato, A., Daly, E., Oishi, A. C., Kim, H.-S., Stoy, P. C., Juang, J.-Y., and Siqueira, M. B.: On the spectrum of soil moisture from hourly to interannual scales, Water Resour. Res., 43, W05428, doi:10.1029/2006WR005356, 2007.

Kjellström, E., Bärring, L., Jacob, D., Jones, R., Lenderink, G., and Schär, C.: Modelling daily temperature extremes: recent climate and future changes over Europe, Climatic Change, 81, 249-265, doi:10.1007/s10584-006-9220-5, 2007.

Koster, R. D., Dirmeyer, P. A., Guo, Z., Bonan, G., Chan, E., Cox, P., Gordon, C. T., Kanae, S., Kowalczyk, E., Lawrence, D., Liu, P., Lu, C. H., Malyshev, S., McAvaney, B., Mitchell, K., Mocko, D., Oki, T., Oleson, K., Pitman, A., Sud, Y. C., Taylor, C. M., Verseghy, D., Vasic, R., Xue, Y., and Yamada, T.: Regions of strong coupling between soil moisture and precipitation, Science, 305, 1138-1140, 2004.

Lam, A., Bierkens, M. F. P., and van den Hurk, B. J. J. M.: Global patterns of relations between soil moisture and rainfall occurrence in ERA-40, J. Geophys. Res., 112, D17116, doi:10.1029/2006JD008222, 2007.

Masson, Valery, Jean-Louis Champeaux, Fabrice Chauvin, Christelle Meriguet, Roselyne Lacaze: A Global Database of Land Surface Parameters at 1-km Resolution in Meteorological and Climate Models. J. Climate, 16, 1261-1282. doi:10.1175/15200442-16.9.1261, 2003.

Maxwell, R. M. and Kollet, S. J.: Interdependence of groundwater dynamics and land-energy feedbacks under climate change, Nat. Geosci., 1, 665-669, doi:10.1038/ngeo315, 2008.

Maxwell, R. M. and Miller, N. L.: Development of a coupled land surface and groundwater model, J. Hydrometeorol., 6, 233-247, doi:10.1175/JHM422.1, 2005.

Miguez-Macho, G., Fan, Y., Weaver, C. P., Walko, R., and Robock, A.: Incorporating water table dynamics in climate modeling: 2. Formulation, validation, and soil moisture simulation, J. Geophys. Res., 112, D10125, doi:10.1029/2006JD008112, 2007.

Pomeroy, J. W., Gray, D. M., Shook, K. R., Toth, B., Essery, R. L. H., Pietroniro, A., and Hedstrom, N.: An evaluation of snow accumulation and ablation processes for land surface modelling, Hydrol. Process., 12, 2339-2367,
doi:10.1002/(SICI)1099-1085(199812)12:15<2339::AIDHYP800>3.0.CO;2-L, 1998.

Radoane, M., Radoane, N., and Dumitriu, D.: Geomorphological evolution of longitudinal river profiles in the Carpathians, Geomorphology, 50(14), 293-306, doi:10.1016/S0169555X(02)00194-0, 2003.

Regionale Zusammenarbeit der Donauländer: Die Donau und ihr Einzugsgebiet - eine hydrologische Monographie, Landesamt für Wasserwirtschaft, München, 1986.

Rihani, J. F., Maxwell, R. M., and Chow, F. K.: Coupling groundwater and land surface processes: Idealized simulations to identify effects of terrain and sub- surface heterogeneity on land surface energy fluxes, Water Resour. Res. , 46 , W12523, doi:10.1029/2010WR009111, 2010.

Savenije, H. H. G.: The runoff coefficient as the key to moisture recycling, J. Hydrol., 176, 219-225, 1996.

Savenije, H. H. G.: The width of a bankfull channel, Lacey's formula explained, J. Hydrol., 276, 176-183, doi:10.1016/S00221694(03)00069-6, 2003.

Schaller, M. F. and Fan, Y.: River basins as groundwater exporters and importers: Implications for water cycle and climate modeling, J. Geophys. Res., 114, D04103, doi:10.1029/2008JD010636, 2009.

Schmitz, O., Karssenberg, D., van Deursen, W., and Wesseling, C.: Linking external components to a spatiotemporal modelling framework: Coupling MODFLOW and PCRaster, Environ. Modell. Softw., 24(9), 1088-1099, doi:10.1016/j.envsoft.2009.02.018, 2009.

Seneviratne, S. I., Lüthi, D., Litschi, M., and Schär, C.: Landatmosphere coupling and climate change in Europe, Nature, 443, 205-209, 2006.

Shah, N., Nachabe, M., and Ross, M.: Extinction Depth and Evapotranspiration from Ground Water under Selected Land Covers, Ground Water, 45, 3, 329-338, 2007.

Sheffield, J., Goteti, G., and Wood, E.: Development of a 50-year high-resolution global dataset of meteorological forcings for land surface modeling, J. Climate, 19, 3088-3111, 2006.

Sophocleous, M.: Interactions between groundwater and surface water: the state of the science, Hydrogeol. J., 10, 52-67, doi:10.1007/s10040-001-0170-8, 2002.

Syroka, J., and Toumi, R.: Scaling and persistence in observed and modelled surface temperature,GRL, 28, 17, 3255-3258, 2001.

Tóth, J.: A theoretical analysis of groundwater flow in small drainage basins. In Proceedings of Hydrologic Symposium Number 3, 75-96, 1963

Trenberth, K. E.: Atmospheric moisture recycling: role of advection and local evaporation, J. Climate, 12, 1368-1381, 1999.

Weisheimer, A., Doblas-Reyes, F. J., Jung, T., and Palmer, T. N.: On the predictability of the extreme summer 2003 over Europe, Geophys. Res. Lett., 38, L05704, doi:10.1029/2010GL046455, 2011.

Wesseling, C., Karssenberg, D., Van Deursen, W., and Burrough, P.: Integrating dynamic environmental models in GIS: the development of a dynamic modelling language, T. GIS, 1, 40-48, 1996.

Yeh, P. J.-F. and Eltahir, E. A. B.: Representation of water table dynamics in a land surface scheme, Pt. I: Model development, J. Climate, 18, 1861-1880, doi:10.1175/JCLI3330.1, 2005.

Yeh, P. J.-F. and Famiglietti, J. S.: Regional Groundwater Evapotranspiration in Illinois, J. Hydrometeor, 10, 464-478, 2009. 